\title{
Ileal digestibility of amino acids in pigs fed diets of different buffering capacity and with supplementary organic acids
}

\author{
Z. Mroz, A.W. Jongbloed, K. Partanen, J.Th.M. van Diepen, \\ K. Vreman and J. Kogut
}

Institute of Animal Science and Health (ID-DLO)

Runderweg 2, 8200 AB Lelystad, The Netherlands

\begin{abstract}
A $2 \times 4$ factorial experiment was carried out with eight SICV-cannulated pigs of $30 \mathrm{~kg}$ initial BW. Dietary buffering capacity (632 vs $578 \mathrm{meq} / \mathrm{kg}$ in Diets $\mathrm{H}$ and L, respectively) in combination with supplementary organic acids (formic acid, fumaric acid or n-butyric acid in acid-equivalent doses of $300 \mathrm{mmol} / \mathrm{kg}$ ) were evaluated for their effects on the apparent ileal digestibility (AID) of protein and amino acids. In the presence of these organic acids in Diet H ("practical"), the AID of crude protein and several amino acids increased by 2.9 to $5.9 \%$-units $(\mathrm{P}<0.05)$. This increase was linear and positively correlated with increasing dietary acidity. Feeding Dict $L$ without organic acids resulted in an increase of urinary acidity by $1.6 \mathrm{pH}$-units, and thereby, ammonia emission from manure was $44 \%$ lower.
\end{abstract}

KEY WORDS: amino acids, ileal digestibility, pigs

\section{INTRODUCTION}

Numerous authors have reported positive effects of dietary acidification with supplementary organic acids (formic, propionic, citric, fumaric) on the performance of weaned or growing pigs (Kirchgessner and Roth, 1978, 1980; Easter, 1988; Ravidran and Kornegay, 1993). The acidity of diets can be also elevated by reducing buffering capacity $(\mathrm{BC})$ with Ca-benzoate $\left(\mathrm{C}_{6} \mathrm{H}_{5} \mathrm{COO}\right)_{2} \mathrm{Ca} \cdot 3 \mathrm{H}_{2} \mathrm{O}$. This is an acidogenic, antifungal salt of benzoic acid $(\mathrm{Ka} \times 105=6.3)$ used in preserving foods. In contrast to organic acids, this salt is reported to lower urinary pH values via biotransformation of its anionic part into hippuric acid (Bridges et al., 1970). A lowered urinary $\mathrm{pH}$ is preferable, from the environmental point of view, since an indoor volatilization of $\mathrm{NH}_{3}$ and its irritative effect on pigs and stockmen can be 
diminished (Mroz et al., 1996). So far, little is known about the influence of Cabenzoate in combination with organic acids on the ileal digestibility (AID) of amino acids. Therefore, the objective of this study was to evaluate the effects of $\mathrm{BC}$ (High vs Low) and organic acid supplementation (formic, fumaric and n-butyric acid) on the AID of $\mathrm{N}$ and amino acids.

\section{MATERIAL AND METHODS}

\section{Animals and experimental design}

Eight barrows (Y x [FL x DL]) of approximately $30 \mathrm{~kg}$ initial BW were fitted with steered ileo-caecal valve (SICV) cannulae under inhalation anaesthesia as described by Mroz et al. (1996a). Pigs were kept in specially designed metabolic pens $(1.15 \mathrm{~m} \times 1.35 \mathrm{~m})$ throughout the whole experimental phase $(75 \mathrm{~d})$, at an average ambient temperature of $18^{\circ} \mathrm{C}$. Quantitative collections of faeces and urine were carried out from unrestrained (freely moving) pigs. The following experimental factors were implemented: (a) BC (Low vs High), and (b) supplementation of organic acids (none [-], formic acid [For], fumaric acid [Fum] or n-butyric acid [But]), arranged in a $2 \times 4$ factorial trial.

\section{Feeding, measurements and statistical analysis}

Basal diets $\mathrm{H}(\mathrm{BC}=632 \mathrm{meq} / \mathrm{kg})$ and $\mathrm{L}(\mathrm{BC}=578 \mathrm{mcq} / \mathrm{kg})$ consisted of tapioca $(27.7 \%)$, wheat middlings $(15.0 \%)$, maize $(11.0 \%)$, extracted soyabean meal $(19.8 \%)$ and maize gluten feed $(10.0 \%)$ as major ingredients. The lower buffering capacity in Diet L was obtained by adding Ca-benzoate $(24 \mathrm{~g} / \mathrm{kg})$ into Diet $\mathrm{H}$ at the expense of $\mathrm{CaCO}_{3}$ and maize starch. Diets $\mathrm{H}$ and $\mathrm{L}$ were fed either alone or with acid-equivalent doses of formic acid $(300 \mathrm{mmol} / \mathrm{kg})$, fumaric acid $(150 \mathrm{mmol} / \mathrm{kg})$ or n-butyric acid $(300 \mathrm{mmol} / \mathrm{kg}$ ). These organic acids were added to the diets at the expense of maize starch. The pigs were fed twice daily at $2.8 \times$ their maintenance requirement, i.e. at $418 \mathrm{~kJ} \mathrm{ME} / \mathrm{BW}^{0.75}$. Chromic oxide $(0.25 \mathrm{~g} / \mathrm{kg})$ was used as a marker. The feed was given to the pigs in a dry form and water was available ad libitum.

Each experimental period lasted $14 \mathrm{~d}$. After $5 \mathrm{~d}$ of adaptation, faeces and urine were collected quantitatively for $5 \mathrm{~d}$, and thereafter ileal digesta were collected twice for $12 \mathrm{~h}$, with a 3 -day interval in-between.

The data were subjected to analysis of variance using the ANOVA procedure of Genstat 5, according to the following model: Yijkl $=\mu+\mathrm{Ai}+\mathrm{Pj}+\mathrm{Bk}+\mathrm{Ol}+(\mathrm{B}$ $\mathrm{x} O) \mathrm{kl}+\varepsilon \mathrm{ijkl}$, where $\mu=$ the overall mean, $\mathrm{A}=$ the effect of the animal $(\mathrm{i}=1 \ldots 8)$, $\mathrm{P}=$ the effect of the period $(\mathrm{j}=1 \ldots 5), \mathrm{B}=$ the effect of the dietary buffering 
capacity $(\mathrm{k}=1,2), \mathrm{O}=$ the effect of the organic acid supplementation $(1=1 \ldots 4)$, and ( = error contribution with average 0 and variance). The differences between the treatments were tested with the Student t-test at $\mathrm{P}<0.05$ and 0.01 .

\section{RESULTS AND DISCUSSION}

The SICV-cannulated pigs had no health problems and grew well $(827 \mathrm{~g} / \mathrm{d})$. In our study, the organic acids in Diet H ("practical") improved significantly the AID of $\mathrm{N}$ and several essential and nonessential amino acids by 2.9 to $5.9 \%$-units (Table 1). This higher AID can most probably be attributed to a stimulatory role of organic acids on endocrine and exocrine pancreatic secretion in pigs, as indicated by Harada et al. (1986) and Sano et al. (1995). These authors found that the pancreatic exocrine responses induced by monocarboxylic acid solutions $(250 \mathrm{mM})$ of $\mathrm{pH} 2.0$ were in the following order: formic acid $>$ lactic acid $>$ pyruvic acid $>>$ acetic acid $>$ butyric acid $>$ propionic acid. Similarly, an intravenous injection of sodium acetate, propionate or butyrate $(625 \mathrm{M} / \mathrm{kg} \mathrm{BW})$ stimulated pancreatic juice secretion and output of protein and amylase (Kato et al., 1989) in 2-week-old calves, which had been given only whole milk and milk replacement and which were considered as nonruminant animals. The responses increased with increasing chain length of the fatty acids, and butyrate was the most effective stimulant.

Acidification of duodenal contents appears to affect pancreatic exocrine secretion via release of secretin, as elevated serum secretin content has been reported in pigs after intestinal acidification with hydrochloric acid or monocarboxylic acids (Moazam et al., 1982). Biliary secretion is also stimulated via released secretin, regulating glucagon and/or insulin levels (Harada et al., 1986). Gálfi and Bokori (1990) reported elevated plasma insulin levels with Na-butyrate supplemented diets. However, Sano et al. (1995) failed to observe any effect of acetate, propionate or butyrate injections on plasma insulin concentrations. Improved apparent digestibility of protein may also be due to an increased absorptive capacity of the intestine. Short-chain fatty acids (SCFAs), such as acetic, propionic and n-butyric acid, produced by microbial fermentation of dietary fibre in the hindgut appear to increase proliferation of epithelial cells in the gastrointestinal mucosa (Sakata et al., 1995). The strength of the effect was found to be in the order of n-butyric $>$ propionic $>$ acetic acid. Increased epithelial cell proliferation has also been observed when SCFAs have been given orally or provided by intravenous or gastrointestinal infusions. Gálfi and Bokori (1990) observed that $0.17 \%$ of Na-butyrate increased the length of ileal microvilli and the depth of caecal crypts in growing pigs. Using short-term culture, Sakata et al. (1995) reported that n-butyric acid increased cryptal cell production rate of pig distal colon. The SCFAs may also have local trophic effects on ileal or colonic mucosa, stimulating gut cpithel- 


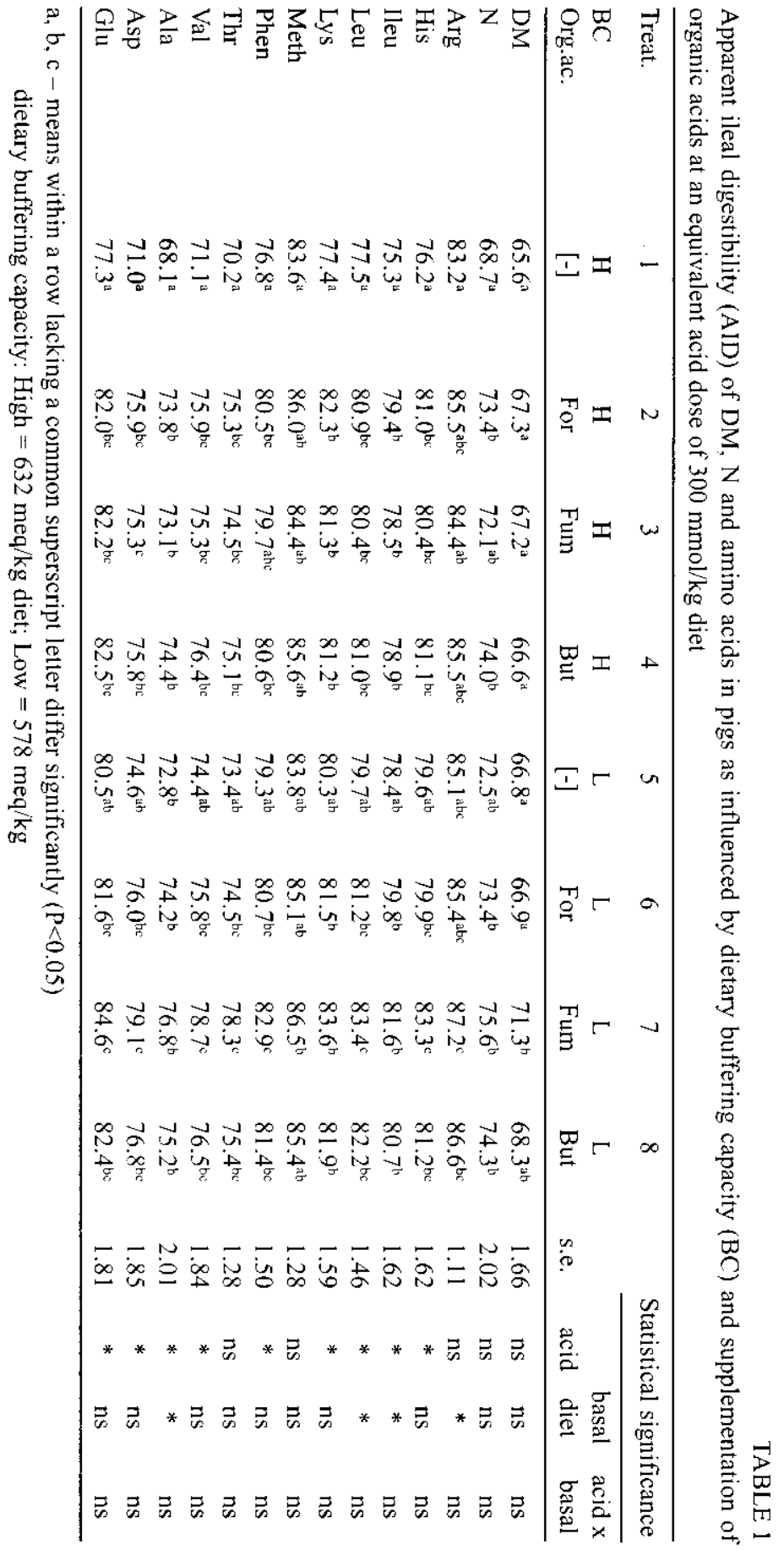


ial cell proliferation via the (afferent) autonomic nervous system, as caecal infusion of SCFAs increased $(\mathrm{P}<0.05)$ jejunal DNA, villous height, surface area, crypt depth, and gastrin in innervated rats (Sakata et al., 1995). The increased epithelial cell proliferation results in longer microvilli, and, therefore, it may increase absorptive surface and capacity in the small and large intestine.

Positive effects of organic acids on the AID of amino acids of a similar range as in our "practical" diet (high buffering capacity) were also reported by Mosenthin et al. (1992) and Blank et al. (1998). They reported that $2 \%$ of propionic or fumaric acid improved $(\mathrm{P}<0.05)$ the AID of Lys, Arg, His, Leu, Phen and Val. Also, Kemme et al. (1995) observed that lactic acid supplementation $(30 \mathrm{~g} / \mathrm{kg})$ improved $(\mathrm{P}<0.05)$ the AID of Arg, Ileu, Lys, Meth, Phen, Tre and Val in diets for fattening pigs. Giesting and Easter (1991) reported a slight, but nonsignificant increase in AID of $\mathrm{N}$ when $2 \%$ of fumaric acid was added to a maize-soyabean meal diet. Bolduan et al. (1988) and Gabert et al. (1995) reported no effect of formic acid on the AID of crude protein and/or amino acids. In contrast, Gabert and Sauer (1995) reported that the AID of CP, Arg, Gly and Tyr decreased linearly $(\mathrm{P}<0.05)$ with increasing level of fumaric acid in the diet. These controversial results may be due to differences in the composition of the dicts.

In our study, Ca-benzoate reduced the urinary $\mathrm{pH}$ on average by $1.6 \mathrm{pH}$-units, i.e., from 7.25 to 5.66. This is in agreement with the previous results of Mroz et al. (1996 b). As a result, ammonia emission was reduced approximately by $44 \%$. The lowered urinary $\mathrm{pH}$ is a result of increased urinary excretion of hippuric acid, an end product of benzoate metabolism. In the liver, benzoates are conjugated with glycine to form hippuric acid or benzoylglucuronic acid, which are rapidly excreted in the urine (Bridges et al., 1970).

\section{CONCLUSIONS}

Formic, fumaric and n-butyric acids $(300 \mathrm{mmol} / \mathrm{kg})$ improved the apparent ileal digestibility of crude protein and amino acids in a pig "practical diet" (buffering capacity $=632 \mathrm{meq} / \mathrm{kg})$ by 2.9 to $5.9 \%$-units $(\mathrm{P}<0.05)$. In a diet of low buffering capacity $(578 \mathrm{meq} / \mathrm{kg})$ containing Ca-benzoate $(24 \mathrm{~g} / \mathrm{kg})$, all three organic acids also exerted a positive effect on the apparent ileal digestibility of these nutrients, but to a lower degree than with the "practical" diet. In general, this increased digestibiliy was linearly and positively correlated with increasing dietary acidity. Feeding the diet of low buffering capacity (with Ca-benzoate and without organic acids) resulted in an increase of urinary acidity by $1.6 \mathrm{pH}$-units, and thereby, ammonia emission from manure was approximately $44 \%$ lower. 


\section{REFERENCES}

Blank R., Mosenthin R., Sauer W.C., 1998. Effect of fumaric acid supplementation and buffering capacity of the diet on ileal digestibilities and the level of microbial metabolites in ileal digesta of early weaned piglets. Proc. Soc. Nutr. Physiol. 7, 109

Bolduan G., Jung H., Schneider R., Block J., Klenke B., 1988. Die Wirkung von Propion- und Ameisensäure in der Ferkelaufzucht. J. Anim. Physiol. Anim. Nutr. 59, 72-78

Bridges J.W., French M.R., Smith R.L., Williams R.T., 1970. The fate of benzoic acid in various species. Biochem. J. 118,47-51

Easter R.A., 1988. Acidification of diets for pigs. In: W. Haresign, D.J.A. Cole (Editors). Recent advances in animal nutrition. Butterworths, London, pp. 61-71

Eidelsburger U., Kirchgessner M., Roth F.X., 1992. Zum Einfluß von Fumarsäure, Salzsäure, Natriumformiat, Tylosin und Toyocerin auf tägliche Zunahmen, Futteraufnahme, Futterverwertung und Verdaulichkeit. 11. Mitteilung. Untersuchungen zur nutritiven Wirksamkeit von organischen Säuren in der Ferkelaufzucht. J. Anim. Physiol. Anim. Nutr. 68, 82-92

Gabert V.M., Sauer W.C., 1995. The effect of fumaric acid and sodium fumarate supplementation to diets for weanling pigs on amino acid digestibility and volatile fatty acid concentrations in ileal digesta. Anim. Feed Sci. Technol. 53, 243-254

Gabert V.M., Sauer W.C., Schmitz M., Ahrens F., Mosenthin R., 1995. The effect of formic acid and buffering capacity on the ileal digestibilities of amino acids and bacterial populations and metabolites in the small intestine of weanling pigs fed semipurified fish meal diets. Can. J. Anim. Sci. 75, 615-623

Gálfi P., Bokori J., 1990. Feeding trial in pigs with a diet containing sodium n-butyrate. Acta Vet. Hung. 38, 3-17

Giesting D.W., Easter R.A., 1991. Effect of protein source and fumaric acid supplementation on apparent ilcal digestibility of nutrients by young pigs. J. Anim. Sci. 69, 2497-2503

Harada, E., Kiriyama H., Kobayashi E., Tsuchita H., 1988. Postnatal development of biliary and pancreatic exocrine secretion in piglets. Comp. Biochem. Physiol. 91 A, 43-51

Harada E., Niiyama M., Syuto B., 1986. Comparison of pancreatic cxocrine secretion via endogenous sccretin by intestinal infusion of hydrochloric acid and monocarboxylic acid in anesthetized piglets. Jpn. J. Physiol. 36, 843-658

Kato S., Asakawa N., Mineo H., Ushijima J., 1989. Effect of short-chain fatty acids on pancreatic exocrine secretion in calves aged 2 weeks and 13 weeks. Jpn. J. Vet. Sci. 51, 1123-1127

Kemme P.A., Jongbloed A.W., Mroz Z., Mäkinen M., 1995. Apparent ilcal amino acid digestibility in pigs as affected by phytate, microbial phytase, and lactic acid. J. Anim. Sci. 73, Suppl. 1, 173

Kirchgessner M., Roth F.X., 1978. Nährstoff- und Energicverdaulichkeit bei Fumarsäure-Zulage. Z. Tierphysiol. Ticrernähr. Futtermittelk. 42, 71-76

Kirchgessner M., Roth F.X., 1980. Verkaulichkcit und Bilanz von Protein, Energie und einigen Mineralstoffen bei Fumarsäurezulagen an Ferkel. Z. Tierphysiol. Tierernähr. Futtermittelk. 44, 239-246

Moazam F., Rodgers B.M., Whecldon S., Kolts B.E., 1982. Secretin levels in plasma and tissue of the neonatal swine. Biol. Neonate 42, 1-7

Mosenthin R., Sauer W.C., Ahrens F., de Lange C.F.M., Bornholdt U., 1992. Effect of dietary supplement of propionic acid, siliceous earth or a combination of these on the energy, protein and amino acid digestibilities and concentrations of microbial metabolites in the digestive tract of growing pigs. Anim. Feed Sci. Technol. 37, 245-255

Mroz Z., Bakker G.C.M., Jongbloed A.W., Dekker R.A., Jongbloed R., van Beers A., 1996a. Apparent digestibility of nutrients in diets with different energy density, as estimated by direct and marker methods for pigs with or without ileo-cecal cannulas. J. Anim. Sci. 74, 403-412 
Mroz Z., Jongbloed A.W., Vreman K., Canh T.T., van Diepen J.Th.M., Kemme P.A., Kogut J., Aarnink A.J.A., 1996b. The effect of different dietary cation-anion supply on excreta composition and nutrient balance in growing pigs. ID-DLO Report No. 96.028, pp. 59

Ravindran, V., Kornegay E.T., 1993. Acidification of weaner pig diets: A review. J. Sci. Food Agric. $62,313-322$

Sakata T, 1987. Stimulatory effect of short-chain fatty acids on epithelial cell proliferation in the rat intestine: a possible explanation for trophic effects of fermentable fibre, gut microbes and luminal trophic factors. Brit. J. Nutr. 58, 95-103

Sakata T., Adachi M., Hashida M., Sato N., Kojima T., 1995. Effect of n-butyric acid on epithelial call proliferation of pig colonic mucosa in short-term culture. Dte Tierärztl. Wochenschr. 102, 163-164

Sano H., Nakamaura E., Takahashi H., Terashima Y., 1995. Plasma insulin and glucagon responses to acute challenges of acetate, propionate, n-butyrate and glucose in growing gilts (Sus scrofa). Comp. Biochem. Physiol. 110A, 375-378 